\title{
ПСИХОЛОГІЧНІ ОСОБЛИВОСТІ ФРУСТРАЦІЙНОЇ ПОВЕДІНКИ ВІЙСЬКОВОСЛУЖБОВЦІВ
}

\author{
Мушкевич Валентин \\ Східноєвропейський національний університет імені Лесі Українки \\ м. Луцьк, Україна \\ vsc.snoop@gmail.com; ORCID iD: 0000-0003-3593-1086
}

\begin{abstract}
Mema. У статті детально вивчено, уточнено й узагальнено матеріали щодо фрустаційної поведінки військовослужбовців, виявлено психологічні особливості фрустраційної поведінки, виокремлено найбільш характерні іiі закономірності та способи перебігу, досліджено ії компоненти, що можуть проявлятись у різних сферах функціонування особистості. Методи. Використано методи спостереження, бесіди, анкетування та тестування. Продіагностовано основні особливості фрустраційної поведінки військовослужбовців за допомогою методик «Самооцінка психічних станів Г. Айзенка», «Соціальна фрустрованість Л. Вассермана». Результати. Відзначено, що військовослужбовці схильні до впевненості в собі та своїх силах, проте вони не завжди готові приймати нововведення й мають проблеми 3 адаптацією до цих змін, намагаються самостійно контролювати ситуацію, яка виникає в житті. Установлено, що у військовослужбовців переважає середній рівень прояву таких психологічних станів, як тривожність, фрустрація, агресивність і ригідність, що породжує

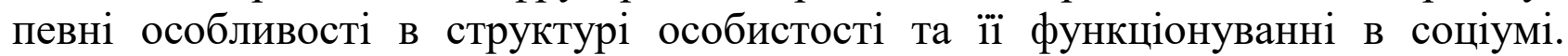
Доведено, що найбільш поширеним типом фрустраційної поведінки військовослужбовців є екстрапунітивні реакції з фіксацією на самозахисті, що свідчить про схильність до ворожості, осуду, звинувачень, докорів і сарказмів; вираженим є активне заперечення власної провини та намагання себе виправдати. Відзначено, що найменш поширеним є тип екстрапунітивної реакції з фіксацією на задоволенні; цей тип характеризується інтерпретацією фруструючої ситуації як корисної або ж такої що приносить задоволення. Висновки. Виявлено, що в більшості військовослужбовців дуже низький рівень соціальної фрустрації, що свідчить про адекватне сприйняття себе в соціумі та нормальну взаємодію в суспільстві. Досліджено, що такі сфери життєдіяльності особистості, як події в державі й суспільстві, матеріальне становище та сфера послуг і побутового обслуговування спричиняють високий ризик для виникнення стану фрустрації. Указано, що результати цього дослідження можуть бути використані в роботі практичного психолога та в таких галузях, як сімейна психологія, загальна психологія, соціальна психологія, військова психологія, психологія праці.
\end{abstract}

Ключові слова: фрустрація, фрустраційна поведінка, військовослужбовці, психічна травма, психологічна адаптація.

ISSN 2308-3743 (Online), ISSN 2227-1376 (Print)

(C) Мушкевич В., 2020. Ця стаття відкритого доступу на умовах CC BY-NC 4.0 
Mushkevych Valentyn. Psychological Features of Frustrational Behavior of the Servicemen. Purpose. The article studies, clarifies and summarizes the materials on the frustrational behavior of servicemen, identifies the psychological features of frustrational behavior, highlights the most characteristic patterns and ways of its course, explores its components that can occur in various areas of personality functioning. Methods. Methods of observation, interviews, questionnaires and testing were used. The main features of frustrational behavior of servicemen are diagnosed with the help of methods «Self-assessment of mental states of G. Eisenko», «Social frustration of L. Wasserman». The Results. It is noted that servicemen are confident in themselves and their abilities, but they are not always ready to accept innovations and have problems adapting to these changes, trying to control the situation that arises themselves. It is established that the servicemen have an average level of manifestation of such psychological states as anxiety, frustration, aggression and rigidity, which gives rise to certain features in the structure of personality and its functioning in the society. It has been proven that the most common type of frustrational behavior of servicemen is extrapunitive reactions with fixation on selfdefense, which indicates a tendency to hostility, condemnation, accusations, reproaches and sarcasm; expressed is the active denial of one's own guilt and attempts to justify oneself. Also pronounced, but less common is the type of extrapunitive reactions with fixation on satisfaction; this type is characterized by the interpretation of frustrating situations as useful or fun. Conclusions. It was found that most servicemen have a very low level of social frustration, which indicates an adequate perception of themselves in the society and normal interaction in the society. It has been proven that such spheres of a person's life as events in the country, financial situation and the lack of provided services cause a high risk of frustration. It is indicated that the results of this study can be used in the work of a practical psychologist and in such fields as family psychology, general psychology, social psychology, military psychology, occupational psychology.

Key words: frustration, frustrational behavior, servicemen, mental trauma, psychological adaptation.

Мушкевич Валентин. Психологические особенности фрустрационного поведения военнослужащих. Цель. В статье подробно изучаются, уточняются и обобщаются материалы о фрустационном поведении военнослужащих, выявляются психологические особенности фрустрационного поведения, выделяются наиболее характерные ее закономерности и способы протекания, исследуются ее компоненты, которые могут проявляться в различных сферах функционирования личности. Memoды. Используются методы наблюдения, беседы, анкетирования и тестирования. Диагностируются основные особенности фрустрационного поведения военнослужащих при помощи методик «Самооценка психических состояний Г. Айзенка», «Социальная фрустрированность Л. Вассермана». Результаты. Отмечается, что военнослужащие уверенные в себе и своих силах, однако они не всегда готовы принимать нововведения и имеют проблемы с адаптацией к этим изменениям, пытаются самостоятельно контро- 
лировать ситуацию, возникающую в жизни. Установлено, что у военнослужащих преобладает средний уровень проявления таких психологических состояний, как тревожность, фрустрация, агрессивность и ригидность, что порождает определенные особенности в структуре личности и ее функционирования в социуме. Доказывается, что наиболее распространенным типом фрустрационного поведения военнослужащих является экстрапунитивные реакции с фиксацией на самозащите, что свидетельствует о склонности к враждебности, осуждению, обвинений, упреков и сарказмов; выраженными являются активное отрицание собственной вины и попытки себя оправдать. Отмечается, что менее распространенный - это тип экстрапунитивной реакции с фиксацией на удовлетворении; этот тип характеризуется интерпретацией фрустрирующих ситуаций как полезных или же таких, что приносят удовольствие. Bыводы. Указывается, что в большинства военнослужащих очень низкий уровень социальной фрустрации, что свидетельствует о адекватном восприятии себя в социуме и о нормальном взаимодействии в обществе. Доказывается, что такие сферы жизнедеятельности личности, как события в государстве и обществе, материальное положение, сфера услуг и бытового обслуживания, вызывают высокий риск для возникновения состояния фрустрации. Указывается, что результаты данного исследования могут быть использованы в работе практического психолога и в таких отраслях, как семейная психология, общая психология, социальная психология, военная психология, психология труда.

Ключевые слова: фрустрация, фрустрационное поведение, военнослужащие, психическая травма, психологическая адаптация.

Постановка наукової проблеми та ії̈ значення. Участь у військових діях на сході України та сама специфіка служби, що передбачає необхідність виконання професійних обов'язків в ускладнених умовах, під впливом емоційних і фізичних стресових факторів, пов'язаних із бойовими діями, можуть впливати на психічний та фізичний стан військовослужбовця. Досить часто такий стан супроводжується зниженням психологічних резервів організму, призводить до порушень життєдіяльності, несприятливих особистісних змін, які в подальшому негативно позначаються на загальному стані здоров'я, працездатності, стосунках з оточенням тощо.

Разом із набуттям військового досвіду військовослужбовці піддаються воєнно-травматичному стресу, зазнають не лише фізичних, а й психологічних травм, що в подальшому ускладнюють їхню адаптацію до мирного життя (Завалко, Кутько, Андрейко \& Єрчкова, 2016; Кокун, Агаєв, Пішко \& Лозінська, 2015; Стаднік, Мельник, Прокопенко \& Валищев, 2019). Причинами складнощів адаптації є тривале перебування в умовах із ризиком для життя, переживання втрати та 
поранень товаришів, негативні очікування, розлука з близькими, переживання стану фрустрації, породженої невідповідністю очікувань реальному стану справ, моральною неготовністю до участі в бойових діях тощо.

Первинне переживання стану фрустрації, отримане під час бойових дій, підсилюється вторинним, що виникає після повернення додому. Стан фрустрації може виникати під час зіткнення з об'єктивними непереборними труднощами (наприклад неможливістю одержати перемогу над супротивником з об'єктивних причин його кращої технічної оснащеності) або суб' єктивними переживаннями (наприклад щодо неможливості побороти ворога, оскільки керівництво не віддає відповідних наказів).

Аналіз досліджень із проблеми. Важливим питанням для психологічної науки є розуміння того, чому одні військовослужбовці переживають стан фрустрації досить інтенсивно, а інші цілком адекватно 3 ним справляються. У такому випадку потрібно звернутися до опису самого поняття фрустрації. Існують різні напрями щодо теоретичного обгрунтування цього феномену. «Великий психологічний словник» трактує цей термін як психологічний стан, викликаний неуспіхом у задоволенні бажання (Мещеряков \& Зінченко, 2009). 3. Фрейд - один iз перших, хто звернув увагу на феномен фрустрації, визначав цей стан, як відсутність задоволення потреб із боку материнської фігури, яка виникає під час блокування досягнення життєвих цілей. Учений стверджував, що за обмеження, заборони, позбавлення певних потягів та бажань 3 індивідом відбуваються зміни, котрі слугують основою для формування основних рис характеру й властивостей особистості. Причиною фрустрації може бути фіксація на одній із ранніх стадій психосексуального розвитку - оральної, анальної, фалічної, латентної, - якщо іiі дія є надто сильною для людини та іï психіка не може впоратись із надмірним впливом незадоволеної потреби. Такий розвиток подій може призвести до патологічного розвитку особистості.

Термін «фрустрація» використовують у різноманітних гіпотезах, концепціях, теоріях під час розгляду питань, що стосуються таких психологічних сфер суб'єкта, як емоційно-вольова, мотиваційна, діяльнісна та поведінкова. Цей феномен досліджували в поєднанні 3 агресією (Д. Доллард, А. Бандура) і стресом (Г. Сельє, Р. Лазарус). Значна частина вчених трактує зазначений феномен як негативний психічний стан. Н. Левітов указує, що «фрустрація являє собою 
складний емоційно-мотиваційний стан, виражається в дезорганізації свідомості, діяльності та спілкуванні, виникає в результаті тривалого блокування цілеспрямованої поведінки об'єктивно нездоланими чи суб'єктивними труднощами» (Левітов, 1964). Фрустрація в деструктивному плані проявляється агресією, реакцією уникнення, депресією й регресією (Левітов, 1964), напруженням та неспокоєм (Махнач \& Бушов, 1988), почуттям байдужості, тривожністю, апатією (Астапов, 1992), заздрощами й ворожістю (Румянцева, 1991), заздрощами та ревнощами (Плотічер, 1969), психосоматичними реакціями (Бандура, 2000).

Аналізуючи бар'єри, які можуть призвести до фрустрації, ми звернулися до думки Т. Дембо, який виокремив внутрішні бар'єри (перешкоджають досягненню цілі) i зовнішні (які не дають змоги індивіду самостійно вийти із ситуації, що склалась). До екстернальних належать ситуації та умови оточення людини, які на неї впливають: фізичні фактори (уключають природні катаклізми, що можуть викликати фрустрацію особистості); соціальні фактори (детермінують неспроможність особистості задовольнити потреби чи досягти значущих для неї цілей у навколишньому середовищі); економічні та фінансові фактори (фруструють задоволення фінансових й економічних потреб особистості). До інтернальних факторів відносять фактори особистості, тригером яких є внутрішній світ особистості. Бар'єри, що з'являються на шляху особистості до мети, можуть бути фізичні, біологічні, психологічні (уключають у себе страх, нестачу знань або навичок), соціокультурні. Зарубіжний дослідник В. Кнаус диференціював бар'єри на епізодичні, які складаються з тимчасових перешкод у розв'язанні проблеми або стану, та тривалі, котрі грунтуються на безперервних невдачах людини в усіх сферах життя, таких як навчання, робота чи любов (Кнаус, 1983).

Вагомий внесок до теорії фрустрації зробив С. Розенцвейг. Учений виокремив три типи фруструючих ситуацій: нестача (privation), тобто відсутність необхідних засобів для досягнення цілі або задоволення потреби; утрата (deprivation), що визначається як утрата предметів чи об'єктів, які раніше задовольняли потреби; конфлікт (conflict), трактується як одночасне існування двох несумісних одне з одним спонукань, амбівалентних почуттів чи відносин (Розенцвейг, 1941). Інші автори основними причинами для виникнення фрустрації визначають непомітні для самої людини, але постійні стреси; дрібні 
невдачі, що підривають упевненість людини й знижують ії самооцінку; розчарування (Сухов, Бодальов \& Казанцев, 2003).

Знаючи причини виникнення фрустрації, важливо виокремити особливості поведінки людини в цьому стані. Типовими для фрустрації реакціями С. Руденський виділяв рухове порушення - безцільні та беззмістовні, невпорядковані реакції; апатію - ослаблення інтересів, млявість, зниження фізичної й психічної активності; агресію та деструкцію - руйнування звичних алгоритмів поведінки; стереотипізацію - тенденцію до сліпого повторення фіксованої поведінки; регресію, яка розуміється або як повернення до поведінкових моделей, що домінували в більш ранні періоди життя індивіда, або як примітивізація поведінки чи падіння якості виконання (Руденський, 2010).

За Н. Майєром, поведінка фрустрованої людини не має мети, тобто втрачає цільову орієнтацію, є не адаптивною, а нова ціль не замінює стару (Майєр, 1942). У цьому плані фрустрація проявляється у двох варіантах - як утрата вольового контролю (дезорганізація поведінки) або як зниження рівня усвідомлення адекватної мотивації (утрата терпіння й надіï). Інший учений - В. Рибніков - зазначає, що всю активну діяльність людини в ситуації фрустрації можна проаналізувати за такими критеріями, як спрямованість і тип реакції. За спрямованістю автор виділяє такі реакції: екстрапунітивні (спрямовані на оточення); інтрапунітивні (спрямовані на самого себе); імпунітивні (фрустрація розглядається як щось, що може бути виправлене саме по собі) (Рибніков, 2000). М. Левітов виокремлює стенічні та астенічні форми проявів фрустрації: до стенічних форм він відносить бажання нападати, ворожість, гнів, недоброзичливість; самовикривання, грубе ставлення до себе. До астенічних реакцій автор уключає почуття суму, невпевненості, безсилля, безнадійності, розпачу, апатії, скутості. Ці реакції є початком виникнення нових рис характеру, але вони можуть бути епізодичними, перехідними (Левітов, 1964).

Загалом, більшість науковців дотримуються думки, що вплив проявів фрустрації на особистість має деструктивний характер і може призвести до невротизації й розвитку психосоматичних захворювань, а також сприяє формуванню таких негативних якостей, як нестриманість, брутальність, непевність, тривожність, підвищена збудливість, безпорадність, ригідність, песимістичність, безініціативність, заздрість, навмисне протиставлення себе навколишнім. Емоційна напруга, що пов'язана з частими фрустраціями, послаблює потребу в 
спілкуванні, призводить до зниження мотивації досягнень. Однак існує думка, що фруструюча ситуація може мати й позитивний вплив на індивіда. Науковці Д. Креч, Р. Кратчфілд та Н. Лівсон вважають, що фрустрація може стимулювати мобілізацію ресурсів організму для досягнення мети, фокусуючи увагу суб'єкта на мотив діяльності щодо бажаної цілі (Креч, Кратчфілд \& Лівсон, 1991).

Отже, аналіз теоретичної літератури дав нам підставу узагальнити, що фрустрація як психологічний феномен являє собою такий психологічний стан, що викликаний неуспіхом чи неможливістю досягнення цілей і задоволення потреб, крах планів та надій. Основними фрустраторами є постійні стреси, невдачі, розчарування, особистісні фактори тощо. Фрустрація характеризується типовими поведінковими реакціями, до яких відносять невпорядковані реакції, апатію, агресію, стереотипізацію, регрес. Проте фрустрація може й мобілізувати людину, спроможну використовувати власні ресурси іiі подолання.

Формулювання мети та завдань. Зважаючи на важливість вираженості стану фрустрації у військовослужбовців, на недостатність даних щодо їхньої фрустраційної поведінки, метою нашого наукового пошуку ставимо дослідження та аналіз особливостей фрустраційної поведінки військовослужбовців, їх теоретичне й емпіричне обгрунтування.

Методи та методики. Для досягнення поставленої мети та виконання завдань використано методи спостереження, бесіди, анкетування, тестування. Для діагностики основних особливостей фрустраційної поведінки військовослужбовців застосовано такі методики, як діагностика самооцінки психічних станів Г. Айзенка, діагностика рівня соціальної фрустрованості Л. Вассермана.

Емпіричне дослідження особливостей фрустраційної поведінки військовослужбовців, учасників бойових дій проведено на базі Центру психологічної допомоги учасникам АТО та їхнім сім'ям при кафедрі практичної та клінічної психології факультету психології та соціології Східноєвропейського національного університету імені Лесі Українки й на базі Волинського обласного госпіталю інвалідів війни.

Вибіркову сукупність становили військовослужбовці - жителі м. Луцька та Волинської області, серед них 100 \% - чоловіки, учасники бойових дій. Вік респондентів - 25-59 років. Військовослуж- 
бовці перебували в зоні бойових дій терміном від трьох місяців до трьох років.

Спостереження спрямовано на збирання психологічних фактів поведінки та діяльності військовослужбовців під час проведення дослідження. Спостереження дало нам змогу виокремити ті поведінкові реакції, які не завжди інтепретувалися, або ті, котрі військові не хотіли описувати чи пояснювати. Наше спостереження обмежилося лише реєстрацією фактів. Перед проведенням заздалегідь розроблено програму й план спостереження, його час, особливості фіксації даних спостереження. Досліджуваний не був попереджений, що за ним спостерігають, тобто його поведінка була невимушена, що уможливило вихід на об'єктивні показники.

Метод бесіди використано як додатковий. Це передбачало обговорення особливостей поведінкових реакцій, стану тощо. Бесіду переважно застосовано для встановлення довірливих стосунків із військовослужбовцями; вона відбувалася невимушено, була відкритою й допомогла уточнити ті моменти, які необхідні під час інтерпретації даних тестування.

Для виявлення та оцінки таких психічних станів особистості, як тривожність, фрустрація, агресивність, ригідність, ми застосували тест «Самооцінка психічних станів» Г. Айзенка в модифікації М. Горської. Цей тест містить чотири блоки по десять тверджень. Кожне твердження потрібно оцінити за критерієм частоти виникнення певного стану, де 2 бали ставиться, якщо стан виникає, 1 - якщо виникає рідко та 0 - якщо певний стан зовсім не характерний для досліджуваного. За автором, твердження першого блоку (1-10 твердження) відносять до шкали тривожності, де діагностується відсутність тривожності (0-7 балів), допустимий рівень або середня тривожність (8-14 балів) і високий рівень тривожності (15-20 балів). Питання другого блоку діагностують прояви фрустрації, де про відсутність, високу стійкість до невдач, відсутність страху перед труднощами свідчать бали 0-7; сума балів 8-14 балів указує на середній рівень фрустрації; про наявність фрустрації, низьку самооцінку, схильність до уникнення труднощів свідчать бали 15-20. Третій блок досліджує прояви агресивності, де 0-7 балів характеризують спокійну й витриману особистість; 8-14 балів визначають середній рівень агресивності та про високий рівень агресивності, нестриманість, труднощі в спілкуванні та роботі з людьми свідчать бали 15-20. Останній (чет- 
вертий) блок виявляє рівень ригідності, де виділяють відсутність ригідності та легке переключення; 8-14 балів - середній рівень; про сильно виражену ригідність, незмінність поведінки, переконань, поглядів, навіть якщо вони відповідають реальним обставинам у житті, свідчать 15-20 балів.

Наступною методикою, яку ми використовували, була «Діагностика рівня соціальної фрустрованості» Л. Вассермана. Досліджуваним потрібно оцінити рівень задоволеності сферами свого життя й здобутками в соціально заданих ієрархіях, взаємостосунками із сім'єю, друзями, колегами, умовами проживання та роботи, ситуацією, що відбувається в державі. Висновки про рівень соціальної фрустрації робляться 3 урахуванням величини середнього бала за кожним пунктом. Чим більшим є бал, тим вищий рівень соціальної фрустрації. Так, виділяють дуже високий рівень фрустрації $(3,5-$ 4 бали); підвищений (3,0-3,4 бала); помірний (2,5-2,9 бала); невизначений $(2,0-2,4$ бала); знижений рівень фрустрації $(1,5-1,9)$; дуже низький (0,5-1,4 бала) і відсутність (майже відсутність) фрустрації 00,5 бала.

Запропоновані методики використовували в комплексі, що дало змогу отримати багатогранні якісні та кількісні показники психологічних особливостей фрустраційної поведінки і іï компонентів у військовослужбовців. Зауважимо, що частина військовослужбовців підозріло ставилася до самого дослідження, задавала багато запитань стосовно нього. Однак основна частина респондентів ставилася до процесу діагностики з розумінням, без зайвих підозр.

Виклад основного матеріалу й обгрунтування отриманих результатів дослідження. Аналіз та інтерпретація даних, отриманих за допомогою таких методів, як спостереження, бесіда й тестування, дали нам підставу виокремити такі показники.

За шкалою «Тривожність» тесту «Самооцінка психічних станів» Г. Айзенка, у 52 \% досліджуваних виявлено низький рівень її прояву, середній - у 39 \%, високий - у 9 \%. За шкалою «Фрустрація» низький рівень іiі прояву діагностовано в 58 \% опитуваних, середній - у $42 \%$, високого рівня цього показника не виявлено. За шкалою «Агресивність» низький рівень притаманний $33 \%$ діагностованих, середній $58 \%$, високий - $9 \%$. За шкалою «Ригідність» низький рівень отримали $24 \%$ респондентів, середній $-67 \%$, низький $-9 \%$. Результати дослідження за цією методикою представлено на рис. 1. 


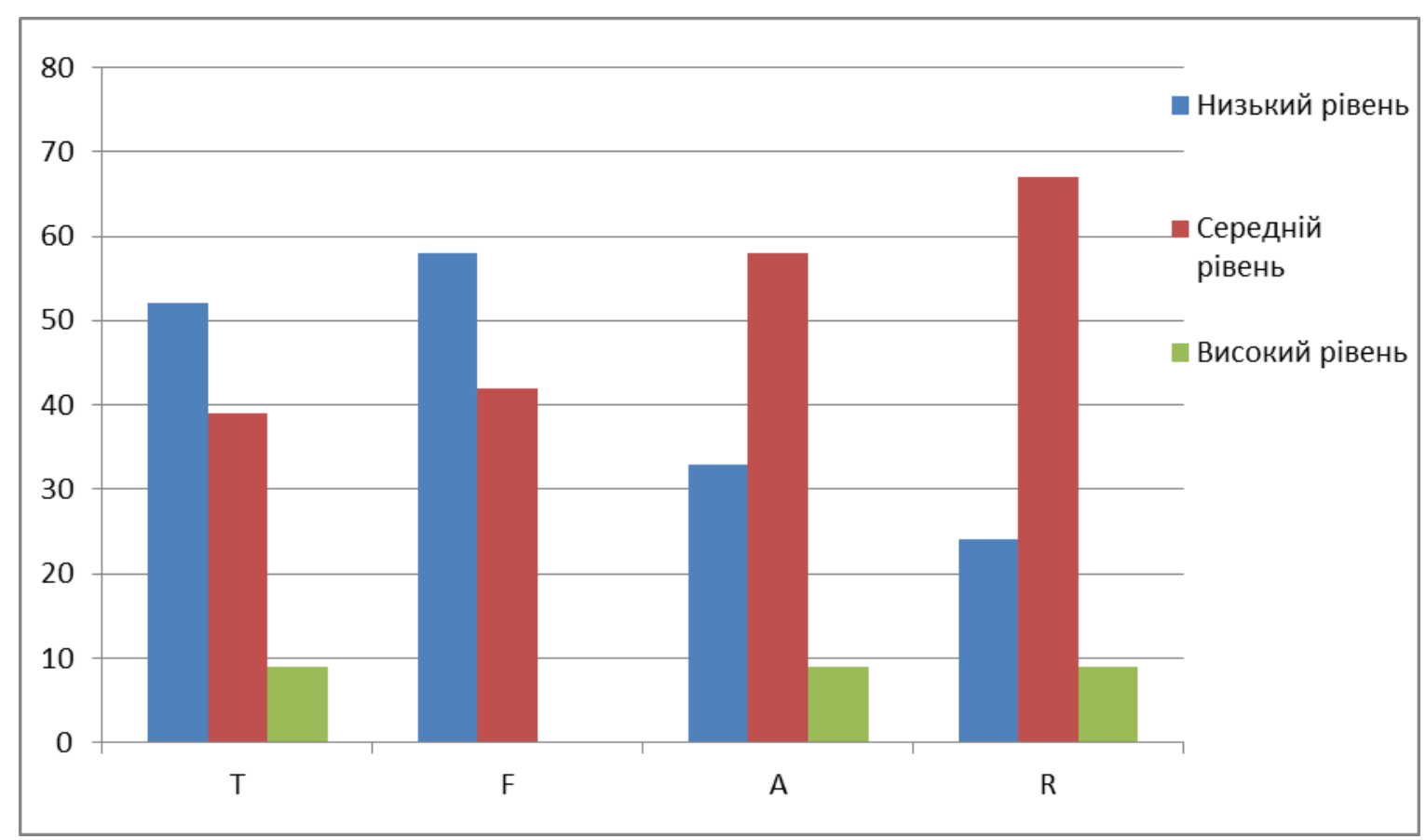

Рис. 1. Самооцінка психічних станів військовослужбовиів за Г. Айзенком, \%

Примітка. $F$ - шкала «Фрустрація»; $T$ - шкала «Тривожність»; $A$ - шкала «Агресія»; $R$ - шкала «Ригідність».

Отже, військовослужбовцям властиві здебільшого низькі й середні рівні таких психічних станів, як тривожність, фрустрація, агресивність та ригідність. На першому місці серед психічних станів досліджуваних за інтенсивністю проявляється ригідність. Зауважимо, що військовослужбовці показали прояв тривожності, агресивності й ригідності високого рівня. Вони мають однаковий відсотковий показник - 9. А от високий рівень фрустрації цій групі досліджуваних не властивий.

Якщо оцінювати загальний рівень досліджуваних психічних станів військовослужбовців, порівняно з максимальним числом (20) за цією методикою, то отримуємо такі результати, які продемонстровано на рис. 2.

Як бачимо, у респондентів домінує стан агресивності, який оцінюється в 9,51 бала серед максимальних 20, стан ригідності має значення 9,15 бала, стан тривожності - 7,75 і найменше проявляється стан фрустрації, що оцінюється у 6,18 бала та не досягає позначки середнього рівня в градації цієї методики. Фрустрація є найменш вираженою серед досліджуваних чотирьох психічних станів у військовослужбовців. У більшості фрустрація відсутня, а решті властивий середній їі рівень. 


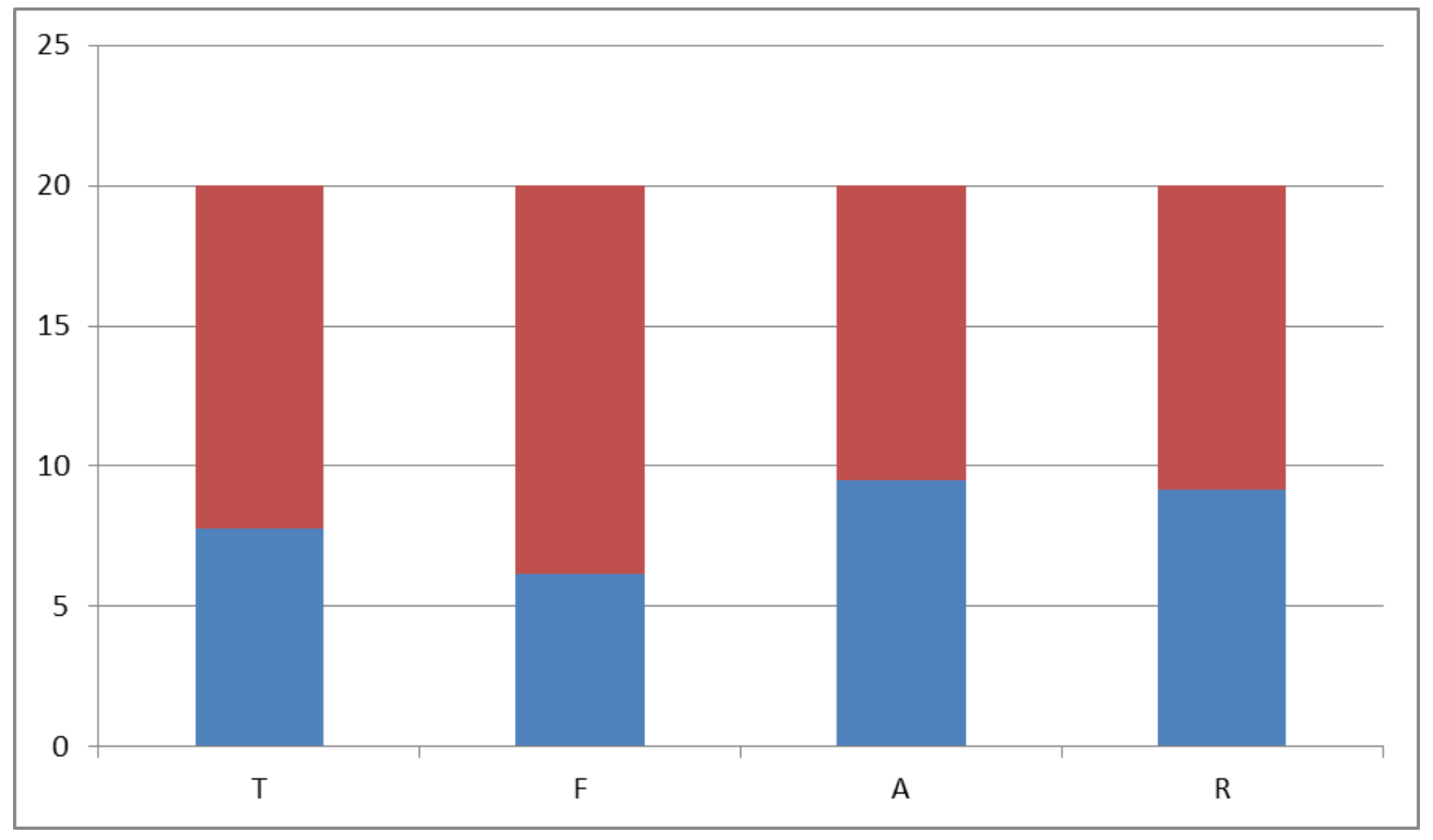

Рис. 2. Рівень психічних станів, порівняно з максимальним числом (20), за методикою Г. Айзенка

Примітка. $F$ - шкала «Фрустрація»; $T$ - шкала «Тривожність»; $A$ - шкала «Агресія»; $R$ - икала «Ригідність».

Отже, отримавши результати самооцінки психічних станів військовослужбовців за методикою Г. Айзенка, можемо зробити висновок, що стан фрустрації високого рівня досліджуваним не властивий. Менше ніж половина продіагностованих можуть відчувати фрустрацію середнього рівня. Здебільшого, військовослужбовцям властивий низький рівень прояву цього стану. Респонденти із середнім рівнем фрустрації схильні звинувачувати себе в неприємностях, які відбулися, навіть якщо на це немає достатніх причин. Окремі ситуації й стани видаються їм безвихідними, може з'являтися відчуття беззахисності та відчаю. У важкі хвилини життя такі люди схильні вдаватися до регресії, поводитися по-дитячому. Респонденти 3 низьким проявом цієї характеристики зазначили, що вони схильні вчитися на власних помилках та не повторювати негативний досвід, у них іноді виникає почуття розгубленості, проте їм під силу самостійно його подолати. Вважають, що безвихідних ситуацій не існує, а неприємності даються задля здобуття нового досвіду й загартовування свого характеру.

Методика «Діагностика соціальної фрустрованості» Л. Вассермана дала нам змогу дослідити особливості фрустраційних чинників, які пливають на військовослужбовців. Під час дослідження цим тестом діагностовані визначали рівень задоволеності сферами свого життя. 
Це дало нам змогу не лише визначити рівень соціальної фрустрованості, а й проаналізувати фактори, які спричиняють указаний феномен. Виявлено, що помірний рівень соціальної фрустрованості властивий $3 \%$ діагностованих, невизначений рівень мають $6 \%$ респондентів, 21\% - низький, дуже низький рівень - у $61 \%$ респондентів, відсутність фрустрованості спостерігаємо в $9 \%$. Дані дослідження за цією методикою представлено на рис. 3.

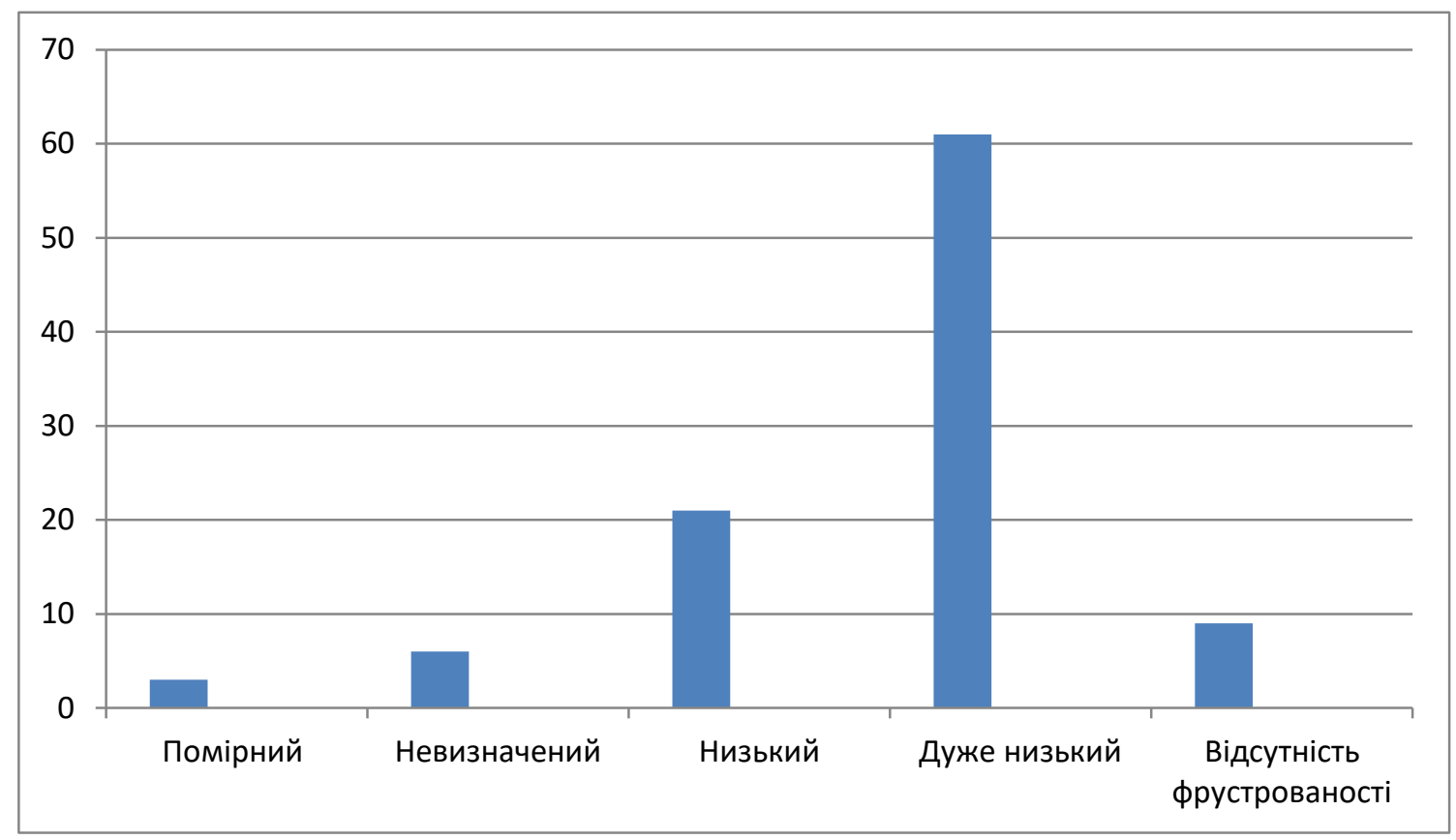

Рис. 3. Прояви соціальної фрустрованості військовослужбовців, \%

Отже, як бачимо 3 рис. 3, військовослужбовці не характеризуються соціальною фрустрованістю. Низький прояв помірного рівня соціальної фрустрованості військовослужбовців може свідчити про часткове задоволення сферами своєї діяльності, що пов'язані 3 роботою, а саме про їі зміст, взаємини з колегами та суб'єктами праці. Усі інші сфери є чинниками повного чи часткового незадоволення або ж діагностованому важко визначитись із відповіддю щодо ставлення до них.

Невизначений рівень фрустрованості, який властивий невеликій частині респондентів, може бути проявом їх невпевненості щодо власного статусу в соціальній ієрархії. Виходячи з відповідей опитуваних, яким властивий невизначений рівень соціальної фрустрованості, можемо зробити висновок, що нам важко визначитись із відповіддю щодо освіти, взаємин із колегами, роботи, а в інших питаннях вони або задоволені, більшою мірою чи повністю незадоволені. До- 
статній рівень задоволення збігається в цих військовослужбовців у сфері проведення дозвілля. Одночасно в них збігається повне незадоволення взаємин із близькими та медичними послугами.

Якщо підрахувати загалом результати трьох груп діагностованих, яким властивий низький і дуже низький рівні фрустрованості та іiі відсутність, то їх відсоток становить 91. Такі показники можуть свідчити про те, що досліджувані військовослужбовці розуміють й усвідомлюють своє місце в соціумі, приймають себе та своє оточення.

У респондентів із низьким рівнем соціальної фрустрованості переважають відповіді, що свідчать про задоволеність і позитивні оцінки власного життя й подій, які відбуваються. Зазвичай, у цих військовослужбовців хороші стосунки 3 колегами по роботі, керівництвом, сім'єю та друзями; вони задоволені своєю роботою, освітою, житловими умовами. Проте більшість опитуваних цієї групи відповіли, що вони не задоволені або швидше не задоволені ситуацією в суспільстві й державі, можливістю проводити відпустку та обирати місце роботи. Дуже низький рівень соціальної фрустрованості свідчить про задоволеність собою й власним життям. Незважаючи на те, що наявні відповіді негативного характеру або невпевненості, загалом, відповіді мають позитивний характер. Проаналізувавши відповіді цієї групи військовослужбовців, можемо стверджувати, що в їхньому житті є 2-3 ситуації, які можуть засмучувати або викликати стан незадоволення, проте їм не приділяється надмірна увага.

Результати визначення рівня соціальної фрустрованості засвідчили незначні прояви або ж іiі відсутність у військовослужбовців, що свідчить про те, що досліджувані змогли знайти своє місце в суспільстві та задоволені своїми соціальними досягненнями в основних аспектах життя. Потрібно зазначити, що, незважаючи на пережиті стресові й психотравмувальні події в респондентів, $\epsilon$ прагнення будувати плани на майбутнє, ставити нові цілі та досягати їх.

Проведене дослідження дало нам змогу виявити сфери відносин $\mathrm{i}$ життя особистості, що можуть провокувати виникнення стану фрустрації. Проаналізувавши отримані результати, ми визначили, що найбільш фруструючими для особистості військовослужбовця $є$ обстановка в суспільстві й державі, матеріальний стан сім’і, сфера послуг та побутового обслуговування. Найменш фруструючими для військовослужбовців, за даними нашого дослідженням, є взаємини 3 дітьми, колегами, суб'єктами праці та рівень освіти. Ці дані відображено на рис. 4. 


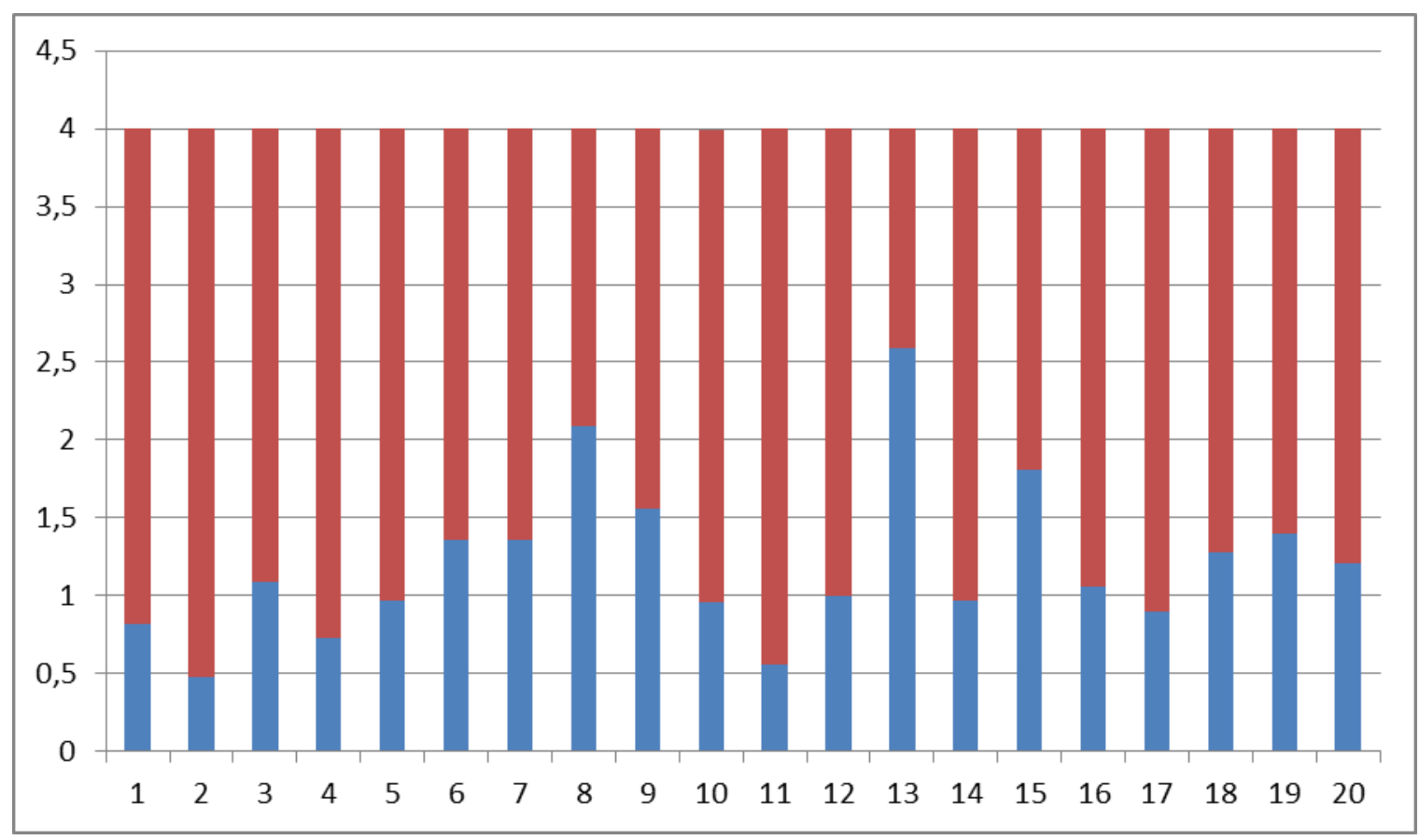

Рис. 4. Співвідношення окремих сочіальних фрустраторів, порівняно з максимальним числом фруструючого фактора (4), за методикою Л. Вассермана, балів

Примітка. 1 - освіта; 2 - взаємини з колегами; 3 - взаємини з керівництвом; 4 - взаємини із суб' 'ктами своєї діяльності; 5 - зміст роботи; 6-умови професійної діяльності; 7 - стан у суспільстві; 8 - матеріальний стан; 9 житлово-побутові умови; 10 - взаємини з дружиною (чоловіком); 11 взаємини з дітьми; 12 - взаємини з батьками; 13 - обстановка в суспільстві та державі; 14 - взаємини з друзями, близькими, знайомим; 15 - сфера послуг та побутового обслуговування; 16 - сфера медичного обслуговування; 17 дозвілля; 18 - можливості проводити відпустку; 19 - можливість обирати місие роботи; 20 - спосіб життя.

Отже, як бачимо 3 рис. 4, найбільш значущими чинниками соціальної фрустрованості військовослужбовців $є$ події в суспільстві та державі, сфера послуг і побутового обслуговування, матеріальний стан та житлово-побутові умови.

Якщо розглядати співвідношення рівнів соціальних фрустраторів, то можна зробити висновок, що основна частина факторів, яка впливає на особистість, може викликати фрустрованість дуже низького рівня. Значимою для військовослужбовців може бути дія лише декількох соціальних чинників, які становлять 5-10\% від їх загальної кількості. Як бачимо на рис. 5, 75 \% соціальних факторів сприяють виникненню фрустрованості дуже низького рівня. 


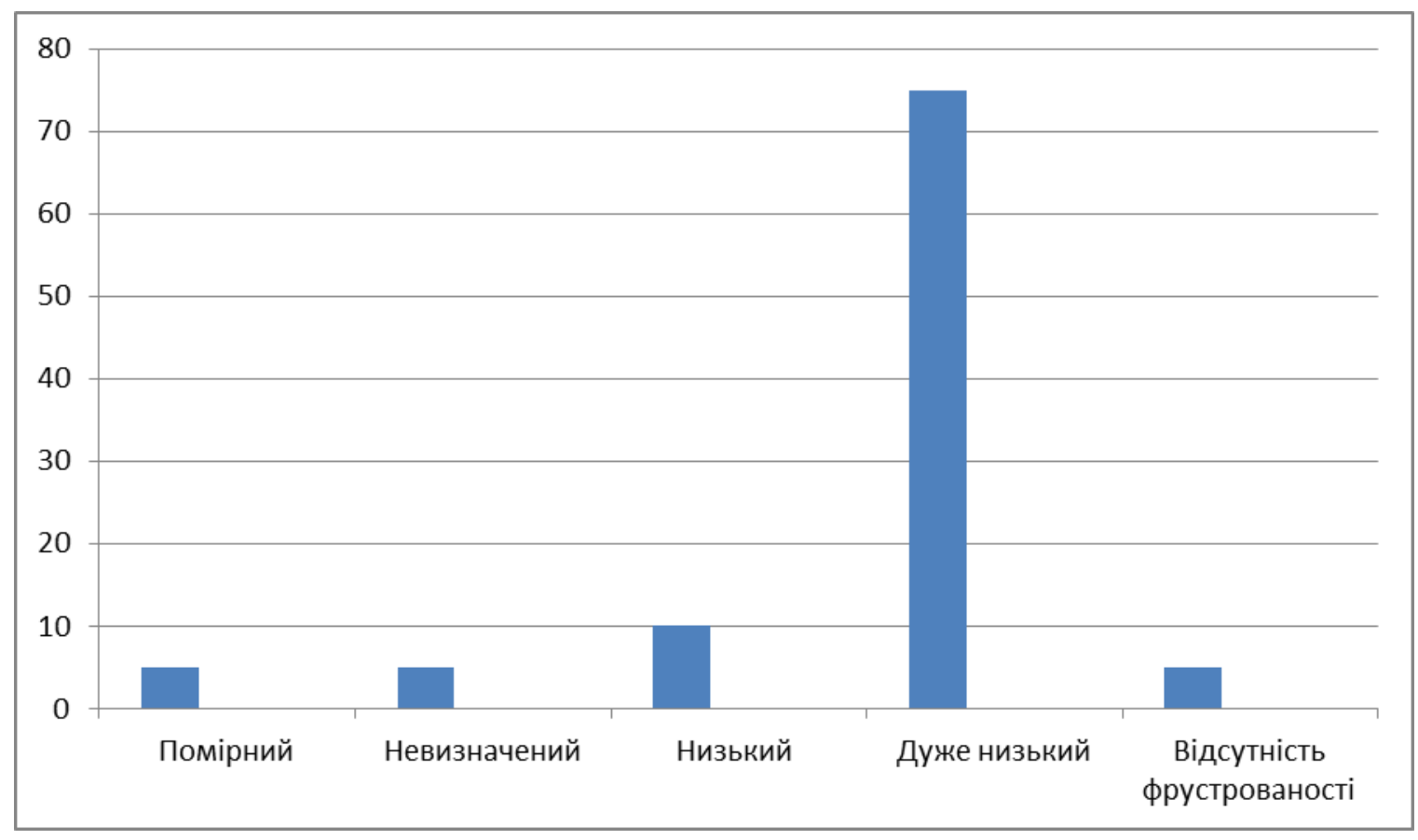

Рис. 5. Відсоткове співвідношення рівнів окремих факторів, що можуть бути чинниками соиіальної фрустрованості, за методикою Л. Вассермана, \%

Як видно з рис. 5, лише декілька сфер життєдіяльності військовослужбовців можуть викликати в них фрустрацію помірного рівня. I такими сферами є обстановка в суспільстві та державі, матеріальний стан діагностованих. Дія основної частини фрустраторів не є значимою для досліджуваних.

Висновки й перспективи подальших досліджень. Отже, узагальнивши аналіз результатів емпіричного дослідження психологічних особливостей фрустраційної поведінки військовослужбовців за допомогою проведених нами методів і методик, можемо зробити такі висновки.

Відзначено, що військовослужбовці схильні до впевненості в собі та своїх силах, проте вони не завжди готові приймати нововведення та мають проблеми з адаптацією до цих змін, намагаються самостійно контролювати ситуацію, яка виникає в житті.

Установлено, що у військовослужбовців переважає середній рівень прояву таких психологічних станів, як тривожність, фрустрація, агресивність і ригідність, що породжує певні особливості в структурі особистості та іiі функціонування в соціумі.

Виявлено, що в досліджуваних яскраво виражені стани ригідності й агресії; ригідність свідчить про слабку адаптацію до нововведень, а агресія проявляється у вибухових реакціях на події та ситуації, що виходять за межі контролю. 
Доведено, що найбільш поширеним типом фрустраційної поведінки військовослужбовців є екстрапунітивні реакції з фіксацією на самозахисті, що свідчить про схильність до ворожості, осуду, звинувачень, докорів і сарказмів; вираженим є активне заперечення власної провини й намагання себе виправдати.

Відзначено, що найменш поширеним є тип екстрапунітивної реакції з фіксацією на задоволенні; цей тип характеризується інтерпретацією фруструючої ситуації як корисної або ж такої, що приносить задоволення.

Установлено, що в більшості військовослужбовців дуже низький рівень соціальної фрустрації, що свідчить про адекватне сприйняття себе в соціумі та нормальну взаємодію в суспільстві.

Військовослужбовці швидше задоволені своїм станом у соціально заданих ієрархіях.

Відзначено, що взаємини з дітьми та дружиною, можливість проводити спільне дозвілля й стосунки з друзями й близькими найменше впливають на виникнення або нівелювання стану фрустрації, тобто сім'я та близьке оточення мають позитивний вплив на стан військовослужбовців.

Досліджено, що такі сфери життєдіяльності особистості, як події в державі й суспільстві, матеріальне становище та сфера послуг і побутового обслуговування спричиняють високий ризик для виникнення стану фрустрації.

Подальші наші дослідження будуть спрямовані на пошук актуальних питань психологічної допомоги тим військовослужбовцям, котрі переживають різні типи фрустрованості й на розробку програми їх реабілітації.

\section{Література}

1. Астапов, В. М. (1992). Функциональный подход к изучению состояния тревоги. Психологический журнал, 13, 5, 111-117.

2. Бандура, А. (2000). Теория сочиального научения. Санкт-Петербург: Евразия, 320 с.

3. Завалко, Ю. М., Кутько М. Ф., Андрейко, М. Ф., Єрчкова, Н. О. (2016). Структура розладів психіки в учасників АТО (пілотне дослідження на клінічному матеріалі стаціонарних хворих). Україна. Здоров'я нації, 4(1), 54-57.

4. Кокун, О. М., Агаєв, Н. А., Пішко, І. О., Лозінська, Н. С. (2015). Основи психологічної допомоги військовослужбовиям в умовах бойових дій: метод. посіб. Київ: НДЦ ГП ЗСУ, 170 с.

5. Креч, Д., Кратчфилд, Р., Ливсон, Н. (1991). Фрустрация. Конфликт. Защита. Вопросы психологии, 6, 69-82. 
6. Левитов, Н. Д. (1964). О психических состояниях человека. Москва: Просвещение, 344 с.

7. Махнач, А. В., Бушов, Ю. В. (1988). Зависимость динамики эмоциональной напряженности от индивидуальных свойств личности. Bonpocbl психологии, 6, 130-134.

8. Мещеряков, Б. Г., Зинченко, В. П. (2009). Большой психологический словарь. Москва: АСТ; Санкт-Петербург: Прайм-Еврознак, 811 с.

9. Плотичер, А. И. (1969). Некоторые соображения по вопросу о фрустрации. Вопросы психологии, 2, 137-141.

10. Руденский, Е. В. (2010). Введение в виктимологию образования: схемьл. URL: http://www.portalus.ru/modules/psychology/rus_readme.php?archive\&id=12 70257391\&start_from\&subaction=showfull\&ucat.

11. Румянцева, Т. Г. (1991). Понятие агрессивности; в современной зарубежной психологии. Вопросы психологии, 1, 81-88.

12. Рыбников, В. Ю. (2000). Психологические прогнозирование надежности деятельности и коррекция дезадаптивных нервно-психических состояний специалистов экстремального профиля. Санкт-Петербург: СПб. ун-т, 205 с.

13. Стаднік, А. В., Мельник, Ю. Б., Прокопенко, Ю. О., Васищев, В. С. (2019). Медико-психологічна допомога та реабілітація військовослужбовців учасників ООС. Науковий вісник Льотної академії, 5, 488-493. doi: 10.33251/ 2522-1477-2019-5-488-493.

14. Сухов, А. Н., Бодалев, А. А., Казанцев, В. Н. (2003). Социальная психология. Москва: Аспект Пресс, 213 с.

15. Knaus, W. (1983). How to conquer your frustration. URL: https://www.rebtnetwork.org/library/How_to_Conquer_Your_Frustrations.pdf

16. Maier, N. (1942). The role of frustration in social movements. Psychological Review, 49, 6, 586-599.

17. Rosenzweig, S. (1941). Need-persistive and ego-defensive reactions to frustration as demostrated by an experiment on repression. Psychological Review, 48, $4,347-349$.

\section{References}

1. Astapov, V. M. (1992). Funkcional'nyj podhod k izucheniju sostojanija trevogi [Functional approach to the study of anxiety]. Psihologicheskij zhurnal, 13, 5, 111-117 (in Russian).

2. Bandura, A. (2000). Teorija social'nogo nauchenija [Theory of social learning]. Sankt-Peterburg: Evrazija, 320 p. (in Russian).

3. Zavalko, Yu. M., Kutko M. F., Andreiko, M. F., Yerchkova, N. O. (2016). Struktura rozladiv psykhiky $\mathrm{v}$ uchasnykiv ATO (pilotne doslidzhennia na klinichnomu materiali statsionarnykh khvorykh) [Structure of mental disorders in antiterrorist operation participants (pilot study on clinical material of inpatients)]. Ukraina. Zdorovia natsii, 4(1), 54-57 (in Ukrainian).

4. Kokun, O. M., Ahaiev, N. A., Pishko, I. O., Lozinska, N. S. (2015). Osnovy psykholohichnoi dopomohy viiskovosluzhbovtsiam $v$ umovakh boiovykh dii: 
metodychnyi posibnyk [Fundamentals of psychological support in terms of military hostilities, handbook]. Kyiv: NDTs HP ZSU, 170 p. (in Ukrainian).

5. Krech, D., Kratchfild, R., Livson, N. (1991). Frustracija. Konflikt. Zashhita [Frustration. Conflict. Protection]. Voprosy psihologii, 6, 69-82 (in Russian).

6. Levitov, N. D. (1964). O psihicheskih sostojanijah cheloveka [About the mental state of a person]. Moskva: Prosveshhenie, 344 p. (in Russian).

7. Mahnach, A. B., Bushov, Ju. V. (1988). Zavisimost' dinamiki jemocional'noj naprjazhennosti ot individual'nyh svojstv lichnosti [The dependence of the dynamics of emotional tension on individual personality traits]. Voprosy psihologii, 6, 130-134 (in Russian).

8. Meshherjakov, B. G., Zinchenko, V. P. (2009). Bol'shoj psihologicheskij slovar' [Great psychological dictionary]. Moskva: AST; Sankt-Peterburg: PrajmEvroznak, 811 p. (in Russian).

9. Ploticher, A. I. (1969). Nekotorye soobrazhenija po voprosu o frustracii [Some Considerations on Frustration]. Voprosy psihologii, 2, 137-141 (in Russian).

10. Rudenskij, E. V. (2010). Vvedenie v viktimologiju obrazovanija: shemy [Introduction to victimology of education: schemes]. URL:http://www.portalus.ru/ modules/psychology/rus_readme.php?archive\&id=1270257391\&start_from\&subacti on=showfull\&ucat (in Russian).

11. Rumjanceva, T. G. (1991). Ponjatie agressivnosti; v sovremennoj zarubezhnoj psihologii [The concept of aggressiveness; in modern foreign psychology]. Voprosy psihologii, 1, 81-88 (in Russian).

12. Rybnikov, V. Ju. (2000). Psihologicheskie prognozirovanie nadezhnosti dejatel'nosti i korrekcija dezadaptivnyh nervno-psihicheskih sostojanij specialistov jekstremal'nogo profilja [Psychological forecasting of reliability of activity and correction of maladaptive neuropsychic states of extreme specialists]. SanktPeterburg: SPb. un-t, 205 p. (in Russian).

13. Stadnik, A. V., Melnyk, Yu. B., Prokopenko, Yu. O., Vasyshchev, V. S. (2019). Medyko-psykholohichna dopomoha ta reabilitatsiia viiskovosluzhbovtsiv uchasnykiv OOS [Medical and psychological assistance and rehabilitation of servicemen - members of the participants OOS]. Naukovyi visnyk Lotnoi akademii, 5, 488-493. doi: 10.33251/2522-1477-2019-5-488-493 (in Ukrainian).

14. Suhov, A. N., Bodalev, A. A., Kazancev, V. N. (2003). Social'naja psihologija [Social psychology]. Moskva: Aspekt Press, 213 p. (in Russian).

15. Knaus, W. (1983). How to conquer your frustration. URL: https://www.rebtnetwork.org/library/How_to_Conquer_Your_Frustrations.pdf (in English).

16. Maier, N. (1942). The role of frustration in social movements. Psychological Review, 49, 6, 586-599 (in English).

17. Rosenzweig, S. (1941). Need-persistive and ego-defensive reactions to frustration as demostrated by an experiment on repression. Psychological Review, 48, 4, 347-349 (in English). 